\title{
Relationship between Dependency on Cell-Phone and the Inside Senses (Approval-Motivation, Feeling Loneliness, Self-Screening and Respecting Social Norms) in Students
}

\author{
Mohammad-Hossein Biglu1, Hossein Dadashzadeh², Fariba Lotfi ${ }^{3}$, Abdolrasoul Safaiyan ${ }^{*}$ \\ ${ }^{1}$ Department of Basic Sciences, Paramedical Faculty, Tabriz University of Medical Sciences, Tabriz, Iran \\ ${ }^{2}$ Razi Psychiatry Hospital, Tabriz, Iran \\ ${ }^{3}$ Tabriz Health Management Services Center, Tabriz, Iran \\ ${ }^{4}$ Tabriz University of Medical Sciences, Tabriz, Iran \\ Email: mh_biglu@yahoo.com, hdadashzadeh@gmail.com, frb.lotfi@gmail.com, *asafaiyana@tbzmed.ac.ir
}

How to cite this paper: Biglu, M.-H., Dadashzadeh, H., Lotfi, F. and Safaiyan, A. (2017) Relationship between Dependency on Cell-Phone and the Inside Senses (Approval-Motivation, Feeling Loneliness, SelfScreening and Respecting Social Norms) in Students. Open Access Library Journal, 4: e3313.

http://dx.doi.org/10.4236/oalib.1103313

Received: December 17, 2016

Accepted: January 15, 2017

Published: January 18, 2017

Copyright $\odot 2017$ by authors and Open Access Library Inc.

This work is licensed under the Creative Commons Attribution International License (CC BY 4.0).

http://creativecommons.org/licenses/by/4.0/

\begin{abstract}
The purpose of current study was to investigate the relationship between the approval-motivation, feeling loneliness, self-screening and respecting on social norms), and its effects on overuse of cellular-phone in Persian speaking students in Iran. A total number of 448 students (224 male and 224 female) were selected randomly from Tabriz University of Medical Sciences in Iran during September 2015-February 2016. For gathering data, we designed a researcher-made questionnaire for determining the practice, knowledge and attitude of university students regarding to the impact of inside senses (the approval-motivation, feeling loneliness, self-screening and respecting on social norms) on overuse of cell-phone. Data were analyzed with the software package of SPSS (version 23). Results showed that the studied parameters regarding to the dependence on cell-phone had statistically significant differences in terms of gender, age, faculty, education-grades, semester, and residence. There was also a statistical correlation between the approval-motivation, feeling loneliness, self-screening and respecting on social norms and over use of cellphone. Among the demographic characteristics, approval motivation was only associated with gender.
\end{abstract}

\section{Subject Areas}

Information Science, Psychology, Sociology 


\section{Keywords}

Addiction, Cell-Phone-Phone, Approval Motivation, Students

\section{Introduction}

One of the human major needs is making interpersonal connection with other people in his/her environment, which is called belonging to the relational community. Feeling of belonging to the similar people causes to feel satisfaction. That is why many people especial the youngers like to keep their relation with their family, friends, classmate and with those who have similar favorites.

The communication technology has the potential ability of making networks by sending and receiving messages in different forms (text, voice, video, audio, picture, and etc.). It has become a widely used tool throughout the world. Cell-phone is an essential part of communication technology that has attracted the attention of people in all ages, especial the young people. They can connect to their favorite social networks by applying their cell-phones everywhere and every time.

Using cell-phone for connecting to social networks is mainly for building relationship with other people, but there are some motivations that force the people to overuse the cell-phone and pleasing long time on social networks. Communication tools such as cell-phone may affect negatively the life of such people. They may lose their concentration during driving, doing their jobs, learning and practicing their courses, and even bothering other people in their environment.

Russell [1] believed that the individuals, who are not able to disregard their cellular-phone, accordingly they will face to the negative consequences of this dependence on their job and daily-life.

Although the results of some studies indicated that there was no major difference between men and women regarding the overuse of cell-phones, however some believes that women use the cell-phone more than men. A study conducted by Oztunc [2] showed that male students use cell-phone more frequently than female students. A significant relationship existed between the problematic use of cell-phone and placement in dormitories, so that students who resided in dormitories, used cell-phones more frequently than those who lived with their family. There was no relationship between the scholar-grades of students with problematic use of cell phone, senses of loneliness, and shame.

Studies showed that the low level of self-esteem may be associated with overuse of cell-phone [3]. Perhaps, the people with low level of self-esteem are in searching improvement, support, encouragement, and admiration among their peers. That is why they tend towards things that may interest them [4] [5]. Therefore, one can say that people with a high motivation level may have the increased tendency towards addictions [5] [6].

Leung [7] investigated the psychological traits such as sensation seeking, self- 
esteem, depressing leisure time, age, and gender in association with addiction on cell-phone among 402 youth between 12 - 20 years old and designed a measurement for addiction on mobile-phone. Results showed that people with high impatience during their leisure time and high thrill-seeking behavior are more prone to become addicted on cell-phone. People with high self-esteem level have less such tendencies and people with low level of self-esteem and high thrillseeking behavior have the most inappropriate use of cell-phone.

Results of other studies showed that young people have more tendencies towards new technologies including cell-phone than the older people. Consequently, they spend more time on their cell-phone and are more exposed to problems associated with excessive use of cell-phone [8] [9]. According to our literature searching in the databases of Web of Science, Medline, Eric, Embase, Magiran, Iranmedex, and google-scholar, we did not find any comprehensive study about the reasons that cause to overuse the cell-phone among the students in the region, therefore we aimed to investigate the correlation between the inside senses (the approval-motivation, feeling loneliness, self-screening and respecting of social norms) and the overuse of cell-phone among students in Tabriz.

\section{Materials and Methods}

A total number of 448 (224 male and 224 female) students were selected randomly from Tabriz University of Medical Sciences in Iran during September 2015-February 2016. The age range of participants was 19 - 50 years; all of them used their own Mobile phones. A total number of 3600 students were studying in different faculties of the University, according to the approval of statistical chancellor of study, $12 \%$ of total population were chosen and went under analysis.

For gathering data, we designed a researcher-made questionnaire for determining the practice, knowledge and attitude of university students regarding the impact of inside senses (the approval-motivation, feeling loneliness, selfscreening and respecting on social norms) on overuse of cell-phone. In addition, the Mobile phone problematic use scale was used to determine the overuse scale of cell-phone.

Data were analyzed with the software package of SPSS (version 23). The ANCOVA test and multifactor linear regression with Stepwise method were used for comparing group of variables in important demographic variables, with controlling the covariate variables. The quantitative results were shown Mean \pm $\mathrm{SE}$ and the maximum level of significance was 0.05 .

\section{Findings}

Analysis of gathered data showed that the studied parameters regarding dependence on cell-phone had statistically significant difference among students in terms of gender, age, faculty, education-grade, semester, and residence; so that males arrived later at appointments than females due to over-use of phone, de- 
creasing the quality and efficiency of education and training. The male students were also at high risk to be unable to pay their phone charges compared to the female students. The approval-motivation for using cell-phone among male students was higher than female students. Results are shown in Table 1.

As shown in Table 2, the study indicated that students aged 18 - 20 are more at risk of suffering efficiency loss, poor concentration, more concern on phone shut-down or missing messages, and physical pain due to over-use of cell-phone compared to the female students.

Regarding to the department and semester, using the phone more than intended time, and physical pain due to excessive use of phone was higher among nursing school compared to another department. Senior students arrived later than other students due to phone over-use. Results are shown in Table 3 and Table 4.

In terms of educational level, undergraduate students used cellular-phone longer than the intended time. They were more furious when forced to shutdown their phones, and were late due to the over-use of phone. They also

Table 1. Descriptive data of important problematic mobile phone use (PU)-scale items according to the gender.

\begin{tabular}{|c|c|c|c|}
\hline & Male & Female & \multirow{2}{*}{ PV } \\
\hline & Mean \pm SE & Mean \pm SE & \\
\hline $\begin{array}{l}\text { Factor 1of MP } \\
\text { I have received mobile phone bills I could not afford to pay. }\end{array}$ & $24.44 \pm 1.74$ & $15.49 \pm 1.47$ & 0.012 \\
\hline My productivity has decreased as a direct result of the time I spend on the mobile phone. & $33.37 \pm 1.83$ & $25.33 \pm 1.71$ & 0.03 \\
\hline My friends don't like it when my mobile phone is off. & $41.67 \pm 1.71$ & $36.67 \pm 1.84$ & 0.047 \\
\hline $\begin{array}{l}\text { Factor } 2 \text { of MP } \\
\text { When out of range for some time, I become preoccupied with the thought of missing a call. }\end{array}$ & $44.23 \pm 1.82$ & $46.68 \pm 1.97$ & 0.029 \\
\hline $\begin{array}{c}\text { Factor } 3 \text { of MP } \\
\text { I am often late for appointments because I'm engaged } \\
\text { on the mobile phone when I shouldn't be. }\end{array}$ & $26.01 \pm 1.78$ & $18.67 \pm 1.49$ & 0.04 \\
\hline $\begin{array}{l}\text { Factor } 4 \text { of MP } \\
\text { I feel anxious if I have not checked for messages or } \\
\text { switched on my mobile phone for some time. }\end{array}$ & $40.16 \pm 1.86$ & $44.25 \pm 1.73$ & 0.012 \\
\hline $\begin{array}{l}\text { Approval motivation } \\
\text { Many times I feel like just flipping a coin in order to decide what I should do. }\end{array}$ & $30.86 \pm 1.68$ & $23.89 \pm 1.63$ & 0.017 \\
\hline I change my opinion in order to please someone else. & $30.14 \pm 1.7$ & $25.56 \pm 1.54$ & 0.048 \\
\hline In order to get along and be liked, I tend to be what people expect me to be. & $43.84 \pm 1.49$ & $37.72 \pm 1.52$ & 0.011 \\
\hline I pretend in order to add entourage. & $28.2 \pm 1.68$ & $21.89 \pm 1.53$ & 0.037 \\
\hline $\begin{array}{l}\text { One should avoid doing things in public which appear to } \\
\text { be wrong to others, even though one knows that she is right. }\end{array}$ & $29.51 \pm 1.86$ & $19.32 \pm 1.57$ & 0.000 \\
\hline $\begin{array}{l}\text { If I hear that someone expresses a poor opinion of me, } \\
\text { I do my best the next time that I see this person to make a good impression. }\end{array}$ & $31.11 \pm 1.82$ & $22.77 \pm 1.42$ & 0.003 \\
\hline It is not important to me that I behave "properly" in social situations. & $38.02 \pm 1.98$ & $28.38 \pm 1.92$ & 0.005 \\
\hline It is hard for me to go on with my work if I am not encouraged to do so. & $42.99 \pm 1.77$ & $35.83 \pm 1.57$ & 0.011 \\
\hline If there is any criticism or anyone says anything about me, I can take it. & $56.34 \pm 1.81$ & $50.22 \pm 1.45$ & 0.019 \\
\hline It is wise to flatter people. & $25.79 \pm 2.01$ & $16.14 \pm 1.66$ & 0.002 \\
\hline
\end{tabular}


Table 2. Descriptive data of important problematic mobile phone use (PU)-scale according to the age.

\begin{tabular}{|c|c|c|c|c|c|}
\hline & $18-20$ & $21-23$ & $24-27$ & $\geq 27$ & \multirow{2}{*}{ PV } \\
\hline & Mean \pm SE & Mean \pm SE & Mean \pm SE & Mean \pm SE & \\
\hline \multicolumn{6}{|l|}{ Factor 1 of MP } \\
\hline $\begin{array}{l}\text { My scholar productivity has decreased as a direct result } \\
\text { of the time I spend on the mobile phone. }\end{array}$ & $34.43 \pm 2.73$ & $34.24 \pm 2.48$ & $23.98 \pm 2.33$ & $24.5 \pm 2.41$ & 0.005 \\
\hline I have been told that I spend more time on MP. & $32.62 \pm 2.93$ & $32.77 \pm 2.68$ & $22.36 \pm 2.45$ & $24.24 \pm 2.55$ & 0.006 \\
\hline My friends and family complain about my use of the mobile phone. & $30.24 \pm 2.82$ & $33.19 \pm 2.57$ & $21.69 \pm 2.54$ & $21.75 \pm 2.63$ & 0.01 \\
\hline My friends don't like it when my mobile phone is switched off. & $43.4 \pm 2.42$ & $43.07 \pm 2.44$ & $32.93 \pm 2.35$ & $37.63 \pm 2.79$ & 0.003 \\
\hline $\begin{array}{c}\text { Factor } 2 \text { of MP } \\
\text { All my friends own a mobile phone. }\end{array}$ & $49.76 \pm 2.67$ & $42.89 \pm 2.56$ & $39.46 \pm 2.49$ & $49.74 \pm 2.9$ & 0.006 \\
\hline $\begin{array}{l}\text { Factor } 3 \text { of MP } \\
\text { I feel anxious if I have not checked for messages or } \\
\text { switched on my mobile phone for some time. }\end{array}$ & $50.94 \pm 2.41$ & $43.22 \pm 2.42$ & $38.62 \pm 2.31$ & $36.25 \pm 2.89$ & 0.002 \\
\hline $\begin{array}{l}\text { I am often late for appointments because } \\
\text { I'm engaged on the mobile phone when I shouldn't be. }\end{array}$ & $28.54 \pm 2.5$ & $24.79 \pm 2.43$ & $16.39 \pm 2.11$ & $20 \pm 2.13$ & 0.009 \\
\hline $\begin{array}{l}\text { I have tried to hide from others how much time } \\
\text { I spend on my mobile phone. }\end{array}$ & $29.25 \pm 2.52$ & $30.46 \pm 2.18$ & $23.98 \pm 2.28$ & $18.94 \pm 2.27$ & 0.012 \\
\hline $\begin{array}{l}\text { I have aches and pains that are } \\
\text { associated with my mobile phone use. }\end{array}$ & $31.6 \pm 2.65$ & $26.26 \pm 2.68$ & $19.72 \pm 2.11$ & $22.19 \pm 2.54$ & 0.03 \\
\hline $\begin{array}{l}\text { More than once I have been in trouble because my } \\
\text { mobile phone has gone off during a meeting, lecture, or in a theatre. }\end{array}$ & $38.81 \pm 2.69$ & $34.75 \pm 2.55$ & $26.22 \pm 2.32$ & $29.85 \pm 2.75$ & 0.003 \\
\hline I have frequent dreams about the mobile phone. & $27.59 \pm 2.84$ & $26.5 \pm 2.38$ & $19.26 \pm 2.11$ & $17.5 \pm 2.42$ & 0.049 \\
\hline \multicolumn{6}{|l|}{$\begin{array}{l}\text { Factor } 4 \text { of MP } \\
\text { Sometimes, when I am on the mobile phone and I am doing } \\
\text { other things, I get carried away with the conversation and } \\
\text { I don't pay attention to what I am doing. }\end{array}$} \\
\hline $\begin{array}{l}\text { The time I spend on the mobile phone } \\
\text { has increased over the last } 12 \text { months. }\end{array}$ & $54.52 \pm 2.74$ & $43.38 \pm 2.56$ & $44.63 \pm 2.58$ & $44.53 \pm 3.04$ & 0.004 \\
\hline $\begin{array}{l}\text { Approval motivation } \\
\text { to react in different ways depending upon the people involved. }\end{array}$ & $20.7 \pm 0.95$ & $18.1 \pm 0.81$ & $17.6 \pm 0.74$ & $16.8 \pm 0.91$ & 0.006 \\
\hline I pretend in order to add entourage. & $12.3 \pm 1.03$ & $10.1 \pm 0.87$ & $9.8 \pm 0.86$ & $7.8 \pm 0.84$ & 0.007 \\
\hline
\end{tabular}

Table 3. Descriptive data of important problematic mobile phone use (PU)-scale according to the Faculty.

\begin{tabular}{|c|c|c|c|c|c|}
\hline \multirow{2}{*}{ Faculty $\rightarrow$} & Health & Management & Nurse & Nutrition & \multirow{2}{*}{ PV } \\
\hline & Mean \pm SE & Mean \pm SE & Mean \pm SE & Mean \pm SE & \\
\hline $\begin{array}{l}\text { I find myself engaged on the mobile phone for } \\
\text { longer periods of time than intended (Factor 2). }\end{array}$ & $36.18 \pm 2.49$ & $36.04 \pm 2.65$ & $44.14 \pm 2.77$ & $31.42 \pm 2.43$ & 0.01 \\
\hline $\begin{array}{l}\text { I have aches and pains that are associated } \\
\text { with my mobile phone use (Factor 3). }\end{array}$ & $22.12 \pm 2.43$ & $27.48 \pm 2.48$ & $30.41 \pm 2.78$ & $19.37 \pm 2.28$ & 0.036 \\
\hline $\begin{array}{l}\text { The time I spend on the mobile phone } \\
\text { has increased over the last } 12 \text { months (Factor } 4 \text { ). }\end{array}$ & $42.04 \pm 2.56$ & $51.36 \pm 2.97$ & $51.62 \pm 2.82$ & $41.67 \pm 2.46$ & 0.019 \\
\hline
\end{tabular}


Table 4. Descriptive data of important problematic mobile phone use (PU)-scale. According to the year of study.

\begin{tabular}{|c|c|c|c|c|}
\hline \multirow{2}{*}{ Year of study $\rightarrow$} & 1st year & 2nd year & $\geq 3$ rd year & \multirow{2}{*}{ PV } \\
\hline & Mean \pm SE & Mean \pm SE & Mean \pm SE & \\
\hline $\begin{array}{l}\text { I have attempted to spend less time on my mobile phone } \\
\qquad \text { (Factor } 1) .\end{array}$ & $53.44 \pm 2.29$ & $43.28 \pm 2.32$ & $45.89 \pm 2.28$ & 0.008 \\
\hline $\begin{array}{l}\text { I am often late for appointments because I'm engaged } \\
\text { on the mobile phone when I shouldn't be (Factor } 3 \text { ). }\end{array}$ & $18.89 \pm 1.89$ & $22.15 \pm 1.96$ & $25.47 \pm 2.16$ & 0.026 \\
\hline
\end{tabular}

experienced more decreased concentration, physical pain, decreased efficiency, sleep disorder, and problem at work because of high phone use. Results are shown in Table 5.

In terms of residence situation, those in dormitories used phone more frequently than non-dormitory students to handle their sadness. They arrived later and were more furious when their phones were off. They also showed decreasing efficiency, physical pain, sleep disorders, and trouble at work due of over-use of phone. Results are shown in Table 6.

The other finding of this study was the statistical relationship between the approval motivation and Factor 1 of dependence on mobile-phone, so that approval motivation had the most incremental link with Factor 1 of phone dependence. Among the demographic characteristics the approval motivation had associated only with gender. Results are shown in Table 7.

\section{Discussion and Conclusion}

The result of analysis showed that some important parameters of problematic use of cell-phone included: phone use over the intended time, arriving late to the appointments. The students experienced decreased concentration, decreased efficiency, and physical pain caused by cell-phone overuse. Inability to pay the phone charges among male students was another problematic issue. Students aged 18 - 20 years, undergraduates, those in dormitories, and nursing students used the cell-phones more frequently than other students. These findings are consistent with results reported by Khazaei about the relationship of age with problematic use of phone. This means that young people were more dependent on phone. The findings are also in agreement with the finding of Aztank regarding dormitory students having more problematic use of phone than nondormitory students. However, results were inconsistent with the findings of Chan as he reported that women had more problematic use of cell-phone compared to men, arguing that female students have less background for social and face-to-face relations and such devices creates more opportunities for selfexpression in relationships due to its capabilities. In addition, there was no difference between students of technical and humanity disciplines in the study by Biglu [10] in terms of dependence to cell-phone-phone. No association was reported between gender and age in terms of dependency on cell-phone by Chan [11]. In the study of Biglu, there was no difference between students of technical and humanity disciplines in terms of dependence on phone, while Chan re- 
Table 5. Descriptive data of important problematic mobile phone use (PU)-scale according to the educational level.

\begin{tabular}{|c|c|c|c|}
\hline \multirow{2}{*}{ Educational level $\rightarrow$} & Bachelor & Master & \multirow{2}{*}{ PV } \\
\hline & Mean \pm SE & Mean \pm SE & \\
\hline \multicolumn{4}{|l|}{ Factor 1 of MP } \\
\hline $\begin{array}{l}\text { I become irritable if I have to switch off my mobile phone for meetings, } \\
\text { dinner engagements, or at the movies. }\end{array}$ & $31.67 \pm 1.93$ & $23.2 \pm 1.76$ & 0.018 \\
\hline My productivity has decreased as a direct result of the time I spend on the mobile phone. & $35.4 \pm 1.82$ & $23.08 \pm 1.65$ & 0 \\
\hline I have been told that I spend more time on MP. & $33.33 \pm 1.95$ & $22.51 \pm 1.77$ & 0 \\
\hline My friends don't like it when my mobile phone is switched off. & $42.7 \pm 1.76$ & $35.52 \pm 1.78$ & 0.002 \\
\hline My friends and family complain about my use of the mobile phone. & $32.67 \pm 1.91$ & $20.8 \pm 1.79$ & 0 \\
\hline $\begin{array}{l}\text { Factor } 2 \text { of MP } \\
\text { I find myself occupied on Mp when I should be doing other things. }\end{array}$ & $36.5 \pm 1.67$ & $29.8 \pm 1.61$ & 0.015 \\
\hline I find myself engaged on the mobile phone for longer periods of time than intended. & $41 \pm 1.81$ & $32.84 \pm 1.86$ & 0.034 \\
\hline $\begin{array}{l}\text { Factor } 3 \text { of MP } \\
\text { I am often late for appointments because I'm engaged on the mobile phone when I shouldn't be. }\end{array}$ & $26.88 \pm 1.77$ & $17.65 \pm 1.47$ & 0.002 \\
\hline I have tried to hide from others how much time I spend on my mobile phone. & $30.09 \pm 1.65$ & $21.49 \pm 1.62$ & 0.003 \\
\hline I have aches and pains that are associated with my mobile phone use. & $29.43 \pm 1.92$ & $20.11 \pm 1.56$ & 0.004 \\
\hline I have frequent dreams about the mobile phone. & $27.23 \pm 1.84$ & $18.21 \pm 1.58$ & 0.005 \\
\hline I lose sleep due to the time I spend on my mobile phone. & $32.78 \pm 1.83$ & $26.59 \pm 1.8$ & 0.024 \\
\hline Factor 4 of MP & & & \\
\hline $\begin{array}{l}\text { Sometimes, when I am on the mobile phone and I am doing other things, } \\
\text { I get carried away with the conversation and I don't pay attention to what I am doing. }\end{array}$ & $45.78 \pm 1.53$ & $39.14 \pm 1.56$ & 0.006 \\
\hline $\begin{array}{l}\text { More than once I have been in trouble because } \\
\text { my mobile phone has gone off during a meeting, lecture, or in a theatre. }\end{array}$ & $36.16 \pm 1.88$ & $28.3 \pm 1.75$ & 0.009 \\
\hline I feel anxious if I have not checked for messages or switched on my mobile phone for some time. & $46.67 \pm 1.73$ & $37.73 \pm 1.83$ & 0.016 \\
\hline $\begin{array}{l}\text { Approval motivation } \\
\text { How many friends you have depends on how nice a person you are. }\end{array}$ & $60.33 \pm 1.77$ & $65.41 \pm 1.54$ & .032 \\
\hline Depending upon the people involved, I react to the same situation in different ways. & $47.87 \pm 1.59$ & $43.55 \pm 1.41$ & .048 \\
\hline
\end{tabular}

Table 6. Descriptive data of important problematic mobile phone use (PU)-scale according to the residence.

\begin{tabular}{|c|c|c|c|}
\hline \multirow{2}{*}{ Residence situation $\rightarrow$} & Dormitory & Non-dormitory & \multirow{2}{*}{ PV } \\
\hline & Mean \pm SE & Mean \pm SE & \\
\hline \multicolumn{4}{|l|}{ Factor 1 of MP } \\
\hline \multicolumn{4}{|l|}{ my mobile phone for meetings, dinner engagements, or at the movies. } \\
\hline My friends and family complain about my use of the mobile phone. & $29.15 \pm 1.73$ & $22.69 \pm 2.06$ & 0.013 \\
\hline I have been told that I spend more time on MP. & $30.59 \pm 1.76$ & $23.48 \pm 2.01$ & 0.005 \\
\hline My productivity has decreased as a direct result of the time I spend on the mobile phone. & $31.8 \pm 1.62$ & $25 \pm 1.97$ & 0.005 \\
\hline $\begin{array}{l}\text { Factor } 2 \text { of MP } \\
\text { If I do not have a mobile phone, my friends would find it hard to get in touch with me. }\end{array}$ & $54.33 \pm 1.49$ & $50.31 \pm 2.3$ & 0.045 \\
\hline I find myself occupied on Mp when I should be doing other things. & $35.59 \pm 1.46$ & $29.12 \pm 1.91$ & 0.009 \\
\hline $\begin{array}{l}\text { Factor } 3 \text { of MP } \\
\text { I have aches and pains that are associated with my mobile phone use. }\end{array}$ & $27.39 \pm 1.66$ & $20.43 \pm 1.86$ & 0.003 \\
\hline I find it difficult to switch off my mobile phone. & $50.35 \pm 1.79$ & $43.25 \pm 2.27$ & 0.008 \\
\hline $\begin{array}{l}\text { I am often late for appointments because } \\
\text { I'm engaged on the mobile phone when I shouldn't be. }\end{array}$ & $24.65 \pm 1.51$ & $18.25 \pm 1.8$ & 0.009 \\
\hline I have frequent dreams about the mobile phone. & $25.09 \pm 1.58$ & $18.75 \pm 1.91$ & 0.014 \\
\hline I lose sleep due to the time I spend on my mobile phone. & $31.8 \pm 1.63$ & $26.08 \pm 2.08$ & 0.015 \\
\hline I have used my mobile phone to talk to others when I was feeling isolated. & $55.39 \pm 1.51$ & $49.69 \pm 2.01$ & 0.03 \\
\hline $\begin{array}{l}\text { Factor } 4 \text { of MP } \\
\text { More than once I have been in trouble because my mobile phone } \\
\text { has gone off during a meeting, lecture, or in a theatre. }\end{array}$ & $34.73 \pm 1.67$ & $28.05 \pm 2.01$ & 0.014 \\
\hline
\end{tabular}


Table 7. The relationship between dependence on mobile phone and approval motivation.

\begin{tabular}{cccc}
\hline \multirow{2}{*}{ AP } & \multicolumn{1}{c}{$\mathrm{R}$} & Adjusted R Square & $\mathrm{PV}$ \\
\cline { 2 - 4 } Mp & 0.455 & 0.202 & 0.000 \\
\hline Constant & $\mathrm{B} \pm \mathrm{SE}$ & Standardized Beta & \\
Mp_F1 & $78.22 \pm 3.7$ & & 0.000 \\
Gender & $0.62 \pm 0.08$ & 0.403 & 0.000 \\
Excluded & $-7.79 \pm 2$ & -0.208 & 0.000 \\
Local & Beta In & Partial Correlation & \\
Faculty & -0.006 & -0.006 & 0.920 \\
Educational level & 0.055 & 0.062 & 0.304 \\
Age & 0.056 & 0.061 & 0.309 \\
Year of study & -0.021 & -0.024 & 0.695 \\
Mp_F2 & -0.069 & -0.077 & 0.198 \\
Mp_F3 & 0.078 & 0.070 & 0.246 \\
Mp_F4 & 0.064 & 0.043 & 0.472 \\
& 0.014 & 0.012 & 0.843 \\
\hline
\end{tabular}

ported no relationship between gender and age with dependency on phone. This may be due to the fact that students were all in one age group. Given the different pattern of cell-phone use in men and women, the type and amount of use varies. In terms of age, the youth are more attracted to new technologies including cell-phone than the elderly. Therefore, young people spend more time on their cell-phone and are excessively more exposed to the problems of over use of mobile-phone. In terms of residence in dormitory, the students spend more time with their phone due to being away from family and sense of social loneliness, and also possibly due to lack of family controls.

The study also showed that approval motivation had the greatest incremental link with Factor 1 of dependence on cell-phone. Among the demographic characteristics, only approval motivation was associated with gender, so that approval motivation score of men was greater than women, which means that men need more approval motivation than women. Young people with low self-esteem or high approval motivation are seeking for confirmation, support, encouragement, and admiration among their peers and that is why they tend towards things that interest them. Therefore, it can be said that the people with high approval motivation tend to use the devices more excessively. Among the demographic characteristics, it was associated only with gender, so that social customs score was lower in women than men. This means that women are more likely to respect their social customs than men.

\section{Acknowledgements}

The authors acknowledge all students who participated in the study. 


\section{Limitation of Study}

This study was carried out among $12 \%$ of total students from this university. Other comprehensive study is need for showing the total population's tendency towards problematic use of cell-phone in the University.

\section{Ethical Issues}

The study was approved by research affairs of Tabriz University of Medical Sciences. All participants were asked to sign an informed written consent before the start of data collection.

\section{Conflict of Interests}

Authors declare that there is no conflict of interests.

\section{References}

[1] Rosell, M.C., Sanchez-Carbonell, X., Jordana, C.G. and Fargues, M.B. (2007) Adolescents and Information and Communications Technologies: Internet, Mobile Phone and Videogames. Papeles del Psicologo, 28, 196-204.

[2] Oztunc, M. (2013) Analysis of Problematic Mobile Phone Use, Feelings of Shyness and Loneliness in Accordance with Several Variables. Procedia-Social and Behavioral Sciences, 106, 456-466. https://doi.org/10.1016/j.sbspro.2013.12.051

[3] Armstrong, L., Phillips, J. and Saling, L. (2000) Potential Determinants of Heavier Internet Usage. International Journal of Human Computer Studies, 53, 537-550. https://doi.org/10.1006/ijhc.2000.0400

[4] Myers, W. (1994) Addictive Sexual Behavior. Journal of American Psychoanalysis Association, 42, 1159-1182.

[5] Baumeister, R. and Vohs, K. (2001) Narcissism as Addiction to Esteem. Psychological Inquiry, 12, 206-210.

[6] Leary, M., Gallagher, B. and Fors, E. (2003) The Invalidity of Disclaimers about the Effects of Social Feedback on Self-Esteem. Personality \& Social Psychology Bulletin, 29, 623-636. https://doi.org/10.1177/0146167203029005007

[7] Leung, L. (2008) Linking Psychological Attributes to Addiction and Improper Use of the Mobile Phone among Adolescents in Hong Kong. Journal of children and media, 2, 93-113. https://doi.org/10.1080/17482790802078565

[8] Caplan, S. (2007) Relations among Loneliness, Social Anxiety, and Problematic Internet Use. CyberPsychology \& Behavior, 10, 234-242. https://doi.org/10.1089/cpb.2006.9963

[9] Robinson P.K. and Birren J.E. (2012) Aging and Technological Advances. Plenum. New York, 31-38.

[10] Biglu, M.H. and Asgharzadeh, A. (2011) The Prevalence of Stress Factors among Medicine Students in Iran. European Psychiatry, 26, 1577.

https://doi.org/10.1016/s0924-9338(11)73281-3

[11] Cağan, O., Unsal, A. and Celik, N. (2014) Evaluation of College Students' the Level of Addiction to Cellular Phone and Investigation on the Relationship between the Addiction and the Level of Depression. Procedia-Social and Behavioral Sciences, 114, 831-839. https://doi.org/10.1016/j.sbspro.2013.12.793 
Submit or recommend next manuscript to OALib Journal and we will provide best service for you:

- Publication frequency: Monthly

- 9 subject areas of science, technology and medicine

- Fair and rigorous peer-review system

- Fast publication process

- Article promotion in various social networking sites (LinkedIn, Facebook, Twitter, etc.)

- Maximum dissemination of your research work

Submit Your Paper Online: Click Here to Submit

Or Contact service@oalib.com 